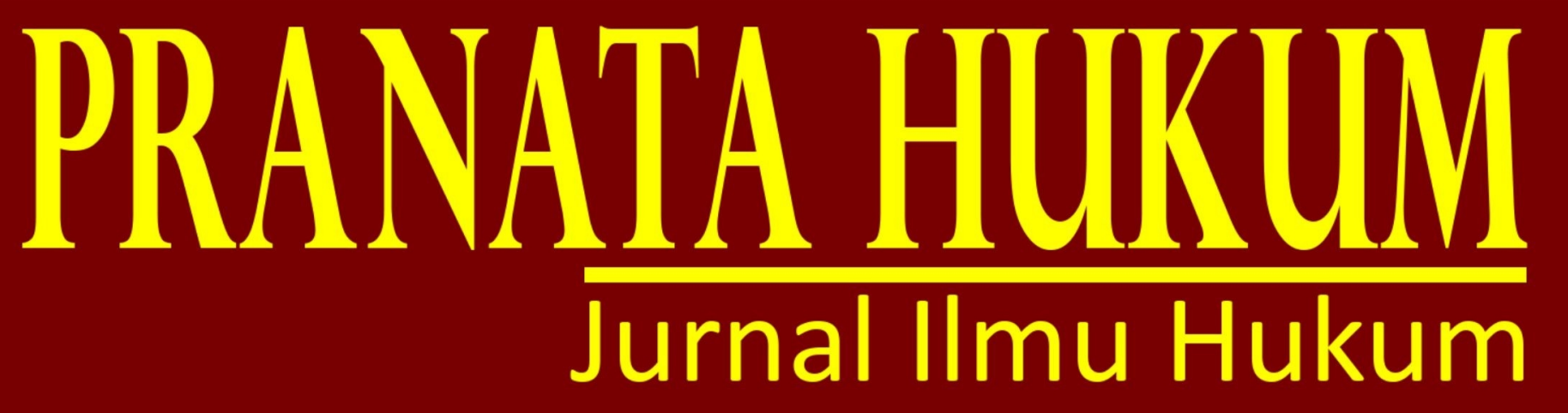

e-ISSN 2685-3213 | p-ISSN 1907-560X

EFEKTIVITAS ASEAN CONVENTION ON COUNTER TERRORISM DI DALAM MEMBERANTAS PEMBAJAKAN DI WILAYAH PERAIRAN ASIA TENGGARA

Rafi Darajati, Muhammad Syafei

PERLINDUNGAN HUKUM PENGGUNA JALAN DARI ANGKUTAN UMUM ONLINE PADA PENGGUNAAN TELEPON SAAT MENGEMUDI KENDARAAN

Rissa Afni Martinouva

ANALISIS PERTANGGUNGJAWABAN PELAKU TINDAK PIDANA MELAKUKAN PENEBANGAN POHON DALAM KAWASAN HUTAN TANPA IJIN YANG BERWENANG

Sukoco SP, Erlina B , Eddy S Wirabhumi

PERLINDUNGAN HUKUM PASIEN PADA BIDAN PRAKTIK MANDIRI DI INDONESIA PASCA DIKELUARKANNYA UNDANG-UNDANG NOMOR 4 TAHUN 2019 TENTANG KEBIDANAN Aditia Arief Firmanto

FUNGSI PENGAWASAN PERADILAN TATA USAHA NEGARA TERHADAP PERBUATAN PEMERINTAH PASCA UNDANG-UNDANG NOMOR 30 TAHUN 2014 TENTANG ADMINISTRASI PEMERINTAHAN Muhammad Rusjana

PELAKSANAAN PENGADAAN BARANG/JASA PEMERINTAH DITINJAU DARI PERPRES NOMOR 16 TAHUN 2018 TENTANG PENGADAAN BARANG/JASA PEMERINTAH DI KANTOR PERTANAHAN KOTA BANDAR LAMPUNG Aryana Wisastra, Baharudin, Indah Satria

KEWAJIBAN TANGGUNG JAWAB SOSIAL PERUSAHAAN (CORPORATE SOCIAL RESPONSIBILITY) DI INDONESIA: ANTARA LEGAL OBLIGATION ATAU MORAL OBLIGATION

Dani Amran Hakim, Dania Hellin Amrina

IMPLEMENTASI PERATURAN MENTERI AGRARIA DAN TATA RUANG/KEPALA BADAN PERTANAHAN NASIONAL NOMOR 13 TAHUN 2017 TENTANG TATA CARA BLOKIR DAN SITA PADA KANTOR PERTANAHAN KOTA BANDAR LAMPUNG

Sholin Erbin M Rajagukguk, Lintje Anna Marpaung, Herlina Ratna Sumbawa Ningrum

PEMBERIAN PATEN OBAT-OBATAN DAN PEMENUHAN HAK ASASI MANUSIA TERHADAP KESEHATAN DI INDONESIA

Chandra Muliawan

\begin{tabular}{c|c|c|c|c|}
\hline $\begin{array}{c}\text { PRANATA } \\
\text { HUKUM }\end{array}$ & $\begin{array}{c}\text { Volume } \\
14\end{array}$ & $\begin{array}{c}\text { Nomor } \\
\mathbf{2}\end{array}$ & $\begin{array}{c}\text { Halaman } \\
96-222\end{array}$ & $\begin{array}{l}\text { Bandar } \\
\text { Lampung } \\
\text { Juli 2019 }\end{array}$ \\
\hline
\end{tabular}




\section{PRANATA HUKUM}

Jurnal Ilmu Hukum

Magister Hukum

Universitas Bandar Lampung

Terbit Pertama Kali, Juli 2006

Terbit Dua Kali Setahun, Setiap Januari dan Juli

PENANGGUNG JAWAB

Rektor Universitas Bandar Lampung

KETUA PENYUNTING

Prof. Dr. Lintje Anna Marpaung, S.H., M.H

WAKIL KETUA PENYUNTING

Dr. Bambang Hartono, S.H., M.Hum

PENYUNTING PELAKSANA

Dr. Tami Rusli, S.H., M.Hum

Dr. Erlina B, S.H., M.H

Dr. Zainab Ompu Jainah, S.H., M.H

Indah Satria, S.H., M.H

Yulia Hesti, S.H., MH

\section{PENYUNTING AHLI (MITRA BESTARI)}

Prof. Dr. I Gusti Ayu Ketut Rachmi Handayani, S.H., M.M (Universitas Sebelas Maret) Prof. Dr. I Gede A.B Wiranata, S.H., M.H (Universitas Lampung)

Dr. Nurhadiantomo, S.H., M.Hum (Universitas Muhammdiyah Surakarta)

Dr. Erina Pane, S.H., M.H (UIN Lampung)

Alamat:

Kampus B Universitas Bandar Lampung

Jl. Z.A Pagar Alam No.89 Labuhan Ratu, Bandar Lampung 35142

Telp: 0721-789825 Fax: 0721-770261

Email: jurnal.mh@ubl.ac.id

Jurnal PRANATA HUKUM dimaksudkan sebagai media komunikasi ,edukasi dan informasi ilmiah bidang ilmu hukum. Sajian dan kemasan diupayakan komunikatif melalui bahasa ilmiah.

Redaksi mengundang semua elemen masyarakat ,baik civitas akademika, praktisi , lembaga masyarakat ,maupun perorangan yang berminat terhadap bidang hukum untuk berpartisipasi mengembangkan gagasan, wawasan, dan pengetahuan melalui tulisan untuk dimuat dalam jurnal ini. Melalui PRANATA HUKUM diharapkan terjadi proses pengembangan bidang hukum sebagai bagian penting dari rangkaian panjang proses memajukan masyarakat bangsa 


\title{
PERLINDUNGAN HUKUM PASIEN PADA BIDAN PRAKTIK MANDIRI DI INDONESIA PASCA DIKELUARKANNYA UNDANG-UNDANG NOMOR 4 TAHUN 2019 TENTANG KEBIDANAN
}

\author{
Aditia Arief Firmanto ${ }^{1}$
}

\begin{abstract}
Legal protection to patient is a theory explained that there are efforts to protect someone's importance by allocating a power to him for acting in its own importance. One of law's characteristics and goals were to give legal protection and guidance to society. Form of legal protection for patient who feel disadvantaged from medical service of Midwife Private-Practice was that there were an effort for preventif law and represif law. According to statue law No. 4 years 2019 about Midwife, legal protection to patient were written on section 61 and section 62, with given penalties on section 41 and section 45. Indonesian Midwife Association's role were doing a preventif monitoring, which monitoring that were done before a government's provision or decree were issued to minimum mistakes and disadvantages in organization's activities. IBI has assignments and responsibilities to protect and control midwife's service quality, also midwife's dedication to their proffesion continuously. IBI did their preventif monitoring by doing assessment of midwife's scholarly abilities and skills, also their competencies when they submitted permission to practice's lisence by giving a recommendation private-pratice letter. Besides, IBI also must monitored midwife's compliance to their ethics proffesion and their capability to run private-practice through divisions, areas, and groups' meetings, also monitoring midwife's service execution by doing workshop and colloquium. Meanwhile, represif monitoring were done according to statue law No. 4 years 2019 about Midwife section 44 and section 4, from giving administration penalties, like direct warning and written warning, administration fine, to revoke midwife's private-practice license.
\end{abstract}

Keywords: legal protection, patient, midwife private-practice

\section{PENDAHULUAN}

Indonesia adalah negara hukum yang mempunyai cita-cita sebagaimana yang tercantum dalam Undang-Undang Dasar 1945 yang mengatakan "melindungi segenap bangsa indonesia dan mencerdaskan kehidupan bangsa, dan ikut melaksanakan ketertiban dunia yang berdasarkan kemerdekaan, perdamaian abadi, dan keadilan sosial. Dalam rangka mencapai cita-cita bangsa tersebut diselenggarakan pembangunan nasional di semua bidang kehidupan yang berkesinambungan yang merupakan suatu rangkaian pembangunan yang menyeluruh, terpadu dan terarah. Salah satu pembangunan nasional adalah pembangunan hukum Indonesia. Pelaksanaan pembangunan hukum Indonesia tidak bisa dilepaskan dengan kegiatan pengembangan ilmu hukum yang dilakukan selama ini. Kegiatan pembangunan hukum nasional yang dilakukan tidak berdiri

\footnotetext{
${ }^{1}$ Dosen Fakultas Hukum Universitas Malahayati, aditia Arieffirmanto@yahoo.co.id
} 
sendiri akan tetapi berkaitan erat dengan pembangunan dibidang lainnya seperti, pembangunan di bidang politik, ekonomi, sosial dan budaya serta pertahanan dan keamanan. Dari interaksi diantara berbagai faktor tersebut diharapakan dapat terbentuk suatu sistem hukum nasional.

Selain pembangunan hukum nasional terdapat program layanan kesehatan yang ditujukkan kepada masyarakat merupakan satu tanggung jawab pemerintah dalam menjamin kesehatan masyarakatnya. Setiap kegiatan dalam upaya untuk memelihara dan meningkatkan derajat kesehatan masyarakat yang setinggitingginya dilaksanakan berdasarkan prinsip nondiskriminatif, partisipatif, dan berkelanjutan dalam rangka pembentukan sumber daya manusia Indonesia, serta peningkatan ketahanan dan daya saing bangsa bagi pembangunan nasional. Peningkatan kualitas tenaga kesehatan, peningkatan layanan kesehatan, penyediaan fasilitas pelayanan kesehatan selalu menjadi perhatian pemerintah.

Berdasarkan Pasal 1 (1) Undang-undang Nomor 36 Tahun 2009 tentang Kesehatan, Kesehatan adalah keadaan sehat, baik secara fisik, mental, spiritual maupun sosial yang memungkiinkan setiap orang untuk hidup produktf secara sosial dan ekonomis. Sumber daya kesehatan diperlukan seseorang untuk mewujudkan empat aspek dalam ksehatan agar terciptanya derajat kesehatan seseorang. Menurut Undang-undang Nomor 36 Tahun 2009 sumber daya kesehatan adalah segala bentuk dana, tenaga, perbekalan kesehatan, sediaan farmasi dan alat kesehatan serta fasilitas pelayanan kesehatan dan teknologi yang dimanfaatkan untuk menyelenggarakan upaya kesehatan yang dilakukan oleh Pemerintah, pemerintah daerah, dan/atau masyarakat.

Sedangkan Hukum Kesehatan adalah rangkaian peraturan perundangundangan dalam bidang kesehatan yang mengatur pelayanan medik dan sarana medik (CST Kansil 1991: 1). Hukum Kesehatan juga dikemukakan oleh PERHUKI, ialah semua ketentuan hukum yang berhubungan langsung dengan pemeliharaan/pelayanan kesehatan dan penerapannya serta hak dan kewajiban baik dari perorangan dan segenap lapisan masyarakat sebagai penerima pelayanan kesehatan maupun dari pihak penyelenggara pelayanan kesehatan dalam segala aspek organisasi, sarana, pedoman-pedoman medik, ilmu pengetahuan kesehatan dan hukum serta sumber-sumber hukum lainnya (Amir Amri 1997: 10). Dari pengertian hukum kesehatan diatas dapat disimpulkan bahwa hukum kesehatan adalah aturan yang mengatur tentang kesehatan dalam hal pelayanan medik sebagai bentuk perlindungan kepada tenaga kesehatan dan masyarakat (pasien).

Pasal 1 Undang Undang Nomor 36 Tahun 2014 tentang Tenaga Kesehatan menyebutkan Tenaga Kesehatan adalah setiap orang yang mengabdikan diri dalam bidang kesehatan serta memiliki pengetahuan dan/atau keterampilan melalui pendidikan di bidang kesehatan yang untuk jenis tertentu memerlukan kewenangan untuk melakukan upaya kesehatan. Menurut Pasal 11 UndangUndang Nomor 36 Tahun 2014 tentang Kesehatan, Tenaga Kesehatan di kelompokkan menjadi beberapa kelompok salah satunya adalah tenaga kebidanan.

Berdasarkan UU No. 36 tahun 2014, Pengelompokan tenaga kesehatan adalah sebagai berikut: 
1. Tenaga medis meliputi dokter, dokter gigi, dokter spesialis, dokter gigi spesialis.

2. Tenaga psikologi klinis ialah psikolog klinis

3. Tenaga keperawatan terdiriatats berbagai jenis perawat

4. Tenaga kebidanan ialah bidan

5. Tenaga kefarmasian meliputi apoteker dan tenaga teknis kefarmasian

6. Tenaga kesehatan masyarakat terdiri atas epidimolog kesehatan, tenaga promosi kesehatan dan ilmu prilaku, pembimbing kesehatan kerja, tenaga addministrasi dan kebijakan kesehatan, tenaga biostatistik dan kependudukan, serta tenaga kesehtan serta reproduksi dan keluarga

7. Tenaga kesehatan lingkungan terdiri atas tenaga saintasi lingkungan, entomolog kesehatan, dan mikrobiolog kesehatan

8. Tenaga gizi terdiri atas nutrisionis dan dietisen

9. Tenaga keterapian fisik terdiri atas fisioterapis, okupasi terapis, terapis wicara, dan akupunktur

10. Tenaga keteknisan medis terdiri atas perekam medis dan informasi kesehatan, tehnik koridovaskuler, tekhinis pelayanan darah, refraksionis optisien optometris, tekhnis gigi, penataan anestesi, terapi gigi dan mulut, dan audiologis

11. Tenaga tehnik biomedika terdiri atas radiografer, elektromedis, ahli teknologi labolatorium medik, fisikawan medik, radio terapis, dan ortotik prostetik

12. Tenaga kesehtaan tradisional terdiri atas tenaga kesehatan tradisional ramuan dan tenaga kesehatan tradisional keterampilan

13. Tenaga kesehatan lain terdiri atas tenaga kesehatan yang ditetapkan oleh mentri yang membidangi urusan kesehatan.

Bidan adalah seseorang yang telah menyelesaikan pendidikan kebidanan yang diakui dan mendapatkan lisensi untuk melaksanakan praktek kebidanan yang diatur dalam Undang-undang Nomor 4 Tahun 2019 Tentang kebidanan. Pengertian lain tentang Bidan adalah seseorang yang telah mengikuti dan menyelesaikan program pendidikan bidan yang telah diakui pemerintah dan lulus ujian sesuai dengan persyaratan yang berlaku.

Kode Etik Bidan Indonesia pertama kali di susun pada tahun 1986 dan disahkan dalam Kongres Nasional Ikatan Bidan Indonesia X tahun 1988, sedangkan petunjuk pelaksanaannya disahkan dalam rapat kerja nasional IBI tahun 1999, kemudian disempurnakan dan disahkan pada kongres nasional IBI ke XII tahun 1989. Sebagai pedoman dalam berprilaku, kode etik bidan Indonesiaterdiri atas 7 bab, yang dibedakan atas tujuh bagian: (Heni, 2005: 47)
a. Kewajiban bidan terhadap klien dan masyarakat
b. Kewajiban bidan terhadap tugasnya
c. Kewajiban bidan terhadap sejawat dan tenaga kesehatan lainnya
d. Kewajiban bidan terhadap profesinya
e. Kewajiban bidan terhadap diri sendiri 
f. Kewajiban bidan terhadap pemerintah, bangsa dan tanah air

g. Penutup.

Bidan dapat menjalankan praktik mandiri dan/atau bekerja di fasilitas pelayanan kesehatan. Bidan yang bekerja di fasilitas pelayanan kesehatan wajib memiliki Surat Izin Kerja Bidan, selanjutnya disingkat SIKB adalah bukti tertulis yang diberikan kepada bidan yang sudah memenuhi persyaratan untuk bekerja di fasilitas pelayanan kesehatan, sedangkan bidan yang menjalankan praktik mandiri wajib memiliki Surat Izin Praktik Bidan selanjutnya disingkat SIPB adalah bukti tertulis yang diberikan kepada bidan yang sudah memenuhi persyaratan untuk menjalankan praktik bidan mandiri.

Bidan praktik mandiri mempunyai hubungan medik dan hubungan hukum dengan pasien. Hubungan medik dan hubungan hukum yang dilakukan oleh bidan dan pasien merupakan suatu hubungan yang obyeknya adalah pemeliharaan kesehatan Ibu dan Anak-anak serta pelayanan kesehatan pada khususnya. Pelaksanaan hubungan antara keduanya selalu diatur dengan peraturan-peraturan agar terjadi keharmonisan dalam melaksanakan hubungan, seperti halnya hubungan tanpa peraturan akan menyebabkan pelanggaran-pelanggaran dan perbuatan melawan hukum.

Beberapa contoh kasus-kasus perbuatan melawan hukum yang dilakukan oleh bidan, yaitu:

1. Kasus di palembang, pelaku IY terhadap rusmiati 17 maret 2016. (Chaidir anwar tanjung, "Bayi meninggal dalam kondisi mengenaskan, pasutri dipalembang dilaporkan bidan", https://news.detik.com/berita/d3168361/bayi-meninggal-dalam-kondisi-mengenaskan-pasutri-dipalembang-laporkan-bidan,

2. Kasus di klinik pratama sang timur, pelaku bidan yuda yulia terhadap Naya 3 september 2017 ("malpraktek dari rahim jebol sampai dijahit acakacakan, ibu satu anak ini curhat difacebook",https: L/manaberita.com/2017/12/malpraktek-dari-rahim-jebol-sampai-dijahitacak-acakan-ibu-satu-anak-ini-curhat-di-facebook/,

3. Kasus di riau, pelaku bidan EN terhadap nurlela horbo 18 Desember 2012 (“ Diduga bayi malpraktik hingga bayi meninggal, bidan di bengkalis dilaporkan kepolisi", https://www.antaranews.com/berita/398499/polisiselidiki-dugaan-malpraktik-seorang-bidan,

4. Kasus dijakarta, pelaku dokter dokter kandungan TG dan HR serta bidan MN terhadap pita sari 16 februari 2015 ("Bayinya meninggal, pita laporkan dokter dan bidan kepolisian”, https://megapolitan.kompas.com Lread/2015/02/16/1813575/Bayinya.Meninggal.Pita.Laporkan.Dokter.dan Bidan.ke.Polisi,

5. Bentuk perlindungan hukum secara perdata terhadap korban oleh tenaga kesehatan yang diatur dalam KUHPerdata, yaitu berupa pengaturan pertanggungjawaban tenaga kesehatan yang melakukan malpraktik untuk memberikan ganti rugi kepada korban malpraktik atas kerugian yang timbul karena : 
a. Tidak ditepatinya perjanjian perjanjian terapeutik yang telah disepakati antara tenaga kesehatan dengan pasien atau wanprestasi (cidera janji), yaitu berdasarkan pasal 1239 KUHPerdata.

b. Perbuatan melawan hukum,yaitu berdasarkan pasal 1365 KUHPerdata.

c. Kelalaian atau kehati-hatian dalam berbuat atau bertindak, yaitu berdasarkan pasal 1366 KUHPerdata.

d. Melalaikan kewajiban berdasarkan pasal 1367 ayat (3).

Selain ditinjau dari hukum perdata, dapat ditinjau pula dari hukum pidana seiring dengan semakin meningkatnya kesadaran hukum masyarakat, dalam perkembangan selanjutnya timbul permasalahan tanggung jawab pidana dengan seorang tenaga kesehatan, khususnya yang menyangkut dengan kelalaian, hal mana dilandaskan pada teori-teori kesalahan dalam hukum pidana. (Ari Yunanto, 2017: 26)

Tanggung jawab pidana disini timbul bila pertama-tama dapat dibuktikan adanya kesalahan profesional, misalnya kesalahan dalam diagnosa atau kesalahn cara-cara pengobatan atau cara-cara perawatan. Dari segi hukum, kesalahan atau/kelalaian akan selalu berkaitan dengan sifat melawan hukumnya suatu perbuatan yang dilakukan oleh seorang yang mampu bertanggung jawab. Seorang dikatakan mampu bertanggung jawab apabila dapat menginsafi makna yang senyatanya dari perbuatannya, dapat menginsafi perbuatannya itu tidak dipandang patut dalam pergaulan masyarakat dan mampu untuk menentukan niat/kehendaknya dalam melakukan perbuatan tersebut. (Andi Hamzah, 2017: 105)

Suatu perbuatan dapat dikategorikan sebagai kriminal malpraktik apabila memenuhi rumusan delik pidana yaitu, perbuatan tersebut harus merupakan perbuatan tercela dan sikap batin yang salah yaitu berupa kesengajaan, kecerobohan, dan kealpaan. Kesalahan atau kelalaian tenaga kesehatan dapat terjadi dibidang hukum pidana, diatur antara lain yaitu :

Pasal 263 KUHP berbunyi :

(1) Barang siapa membuat surat palsu atau memalsukan surat, yang dapat menerbitkan sesuatu hak, sesuatu perjanjian (kewajiban) atau sesuatu pembebasan utang, atau yang boleh dipergunakan sebagai keterangan bagi sesuatu perbuatan, dengan maksud akan menggunakan atau menyuruh orang lain menggunakan surat-surat itu seolah-olah surat itu asli dan tidak dipalsukan, maka kalau mempergunakannya dapat mendatangkan sesuatu kerugian dihukum karena pemalsuan surat, dengan hukuman penjara selamalamanya enam tahun.

(2) Dengan hukuman serupa itu juga dihukum, barangsiapa dengan sengaja menggunakan surat palsu atau yang dipalsukan itu seolah-olah surat itu asli dan tidak dipalsukan, kalau hal mempergunakan dapat mendatangkan sesuatu kerugian

Pasal 267 KUHPberbunyi : 
(1) Seorang dokter yang dengan sengaja memberikan surat keterangan palsu tentang ada atau tidaknya penyakit, kelemahan atau cacat, diancam dengan pidana penjara paling lama empat tahun

(2) Jika keterangan diberikan dengan maksud untuk memasukkan seseorang ke dalam rumah sakit jiwa atau untuk menahannya di situ, dijatuhkan pidana penjara paling lama delapan tahun enambulan.

(3) Diancam dengan pidana yang sama, barang siapa dengan sengaja memakai surat keterangan palsu itu seolah-olah isinya sesuai dengan kebenaran.

Pasal 294 ayat (2) KUHP berbunyi :

Diancam dengan pidana yang sama:

(1) Pejabat yang melakukan perbuatan cabul dengan orang yang karena jabatan adalah bawahannya, atau dengan orang yang penjagaannya dipercayakan atau diserahkan kepadanya;

(2) Pengurus, dokter, guru, pegawai, pengawas atau pesuruh dalam penjara, tempat pekerjaan negara, tempat pen- didikan, rumah piatu, rumah sakit, rumah sakit jiwa atau lembaga sosial, yang melakukan perbuatan cabul dengan orang yang dimasukkan ke dalamnya.

Pasal 299 KUHP berbunyi :

(1) Barangsiapa dengan sengaja mengobati seorang perempuan atau mengerjakan sesuatu perbuatan terhadap seorang perempuan dengan memberitahukan atau menimbulkan pengharapan bahwa oleh karena itu dapat gugur kandungannya, dihukum penjara selama - lamanya empat tahun atau denda sebanyak banyaknya Rp 45.000.

(2) Kalau sitersalah mengerjakan itu karena mengharapkan keuntungan, dari pekerjaan atau kebiasaannya dalam melakukan kejahatan itu, atau kalau ia seorang tabib, dukun beranak (bidan) atau tukang membuat obat, hukuman itu, dapat ditambah dengan sepertiganya.

(3) Kalau sitersalah melakukan kejahatan itu dalam jabatannya dapat ia dipecat dari pekerjaannya itu.

Pasal 304 KUHPberbunyi :

Barangsiapa dengan sengaja menyebabkan atau membiarkan orang dalam kesengsaraan, sedang ia wajib memberi kehidupan, perawatan atau pemeliharaan pada orang itu karena hukum yang berlaku atasnya atau karena menurut perjanjian, dihukum penjara selama - lamanya dua tahun delapan bulan, atau denda sebanyak - banyaknya Rp 4.500.

Pasal 322 KUHPberbunyi :

(1) Barangsiapa dengan sengaja membuka sesuatu rahasia, yang menurut jabatannya atau pekerjaannya, baik yang sekarang, maupun yang dahulu, ia diwajibkan menyimpannya, dihukum penjara selama - lamanya sembilan bulan atau denda sebanyak - banyaknya Rp 9000.

(2) Jika kejahatan ini dilakukan terhadap seorang yang ditentukan maka perbuatan itu hanya dituntut atas pengauan orang itu. 
Pasal 344 KUHP berbunyi:

Barang siapa merampas nyawa orang lain atas permintaan orang itu sendiri yang jelas dinyatakan dengan kesungguhan hati, diancam dengan pidana penjara paling lama dua belas tahun.

Pasal 347 KUHP berbunyi :

(1) Barang siapa dengan sengaja menggugurkan atau mematikan kandungan seorang wanita tanpa persetujuannya, diancam dengan pidana penjara paling lama dua belas tahun.

(2) Jika perbuatan itu mengakibatkan matinya wanita tersebut diancam dengan pidana penjara paling lama lima belas tahun.

Pasal 348 KUHP berbunyi :

(1) Barang siapa dengan sengaja menggugurkan atau mematikan kandungan seorang wanita dengan persetujuannya, diancam dengan pidana penjara paling lama lima tahun enam bulan.

(2) Jika perbuatan itu mengakibatkan matinya wanita tersebut, diancam dengan pidana penjara paling lama tujuh tahun.

Pasal 349 KUHP berbunyi :

Jika seorang dokter, bidan atau juru obat membantu melakukan kejahatan berdasarkan pasal 346, ataupun melakukan atau membantu melakukan salah satu kejahatan yang diterangkan dalam pasal 347 dan 348, maka pidana yang ditentukan dalam pasal itu dapat ditambah dengan sepertiga dan dapat dicabut hak untuk menjalankan pencarian dalam mana kejahatan dilakukan.

Pasal 351 KUHP berbunyi:

(1) Penganiayaan diancam dengan pidana penjara paling lama dua tahun delapan bulan atau pidana denda paling banyak empat ribu lima ratus rupiah

(2) Jika perbuatan mengakibatkan luka-luka berat, yang bersalah diancam dengan pidana penjara paling lama lima tahun.

(3) Jika mengakibatkan mati, diancam dengan pidana penjara paling lama tujuh tahun.

(4) Dengan penganiayaan disamakan sengaja merusak kesehatan.

(5) Percobaan untuk melakukan kejahatan ini tidak dipidana

Pasal 359 KUHPberbunyi :

Barang siapa karena kesalahannya (kealpaannya) menyebabkan orang lain mati, diancam dengan pidana penjara paling lama lima tahun atau pidana kurungan paling lama satu tahun.

Pasal 360 KUHP berbunyi :

(1) Barang siapa karena kesalahannya (kealpaannya) menyebabkan orang lain mendapat luka-luka berat, diancam dengan pidana penjara paling lama lima tahun atau pidana kurungan paling lama satu tahun.

(2) Barang siapa karena kesalahannya (kealpaannya) menyebahkan orang lain lukaluka sedemikian rupa sehingga timhul penyakit atau halangan menjalankan pekerjaan jabatan atau pencarian selama waktu tertentu, diancam dengan pidana penjara paling lama sembilan bulan atau pidana kurungan 
paling lama enam bulan atau pidana denda paling tinggi empat ribu lima ratus rupiah.

Pasal 361 KUHP berbunyi :

Jika kejahatan yang diterangkan dalam bab ini dilakukan dalam menjalankan suatu jabatan atau pencarian, maka pidana ditambah dengan sepertiga dan yang bersalah dapat dicahut haknya untuk menjalankan pencarian dalam mana dilakukan kejahatan dan hakim dapat memerintahkan supaya putusannya diumumkan

Pasal 531 KUHP berbunyi :

Barang siapa ketika menyaksikan bahwa ada orang yang sedang menghadapi maut tidak memberi pertolongan yang dapat diberikan padanya tanpa selayaknya menimbulkan bahaya bagi dirinya atau orang lain, diancam, jika kemudian orang itu meninggal, dengan pidana kurungan paling lama tiga bulan atau pidana denda paling banyak empat ribu lima ratus rupiah.

Adanya perbedaan antara tindak pidana biasa dengan "tindak pidana medis", yaitu pada "penyebabnya", walaupun berakibat fatal tetapi jika tidak ada unsur kelalaian atau kesalahan maka tenaga kesehatan tidak dapat dipersalahkan.

Beberapa contoh dari criminal malpractice yang berupa kesengajaan adalah melakukan aborsi tanpa indikasi medis, membocorkan rahasia kedokteran, tidak melakukan pertolongan seseorang yang sedang dalam keadaan emergency, melakukan eutanasia, menerbitkan surat keterangan dokter yang tidak benar, membuat visum etrepertum yang tidak benar dan memberikan keterangan disidang pengadilan dalam kapasitas sebagai ahli.(https://prasko17.blogspot.com/2011/03/perbedaan-malpraktek-dankelalaian.html,diakses hari selasa, 9 Juli 2019 ,jam 09:35. wib).

Adapun dasar aturan Undang-Undang No. 4 Tahun 2019 tentang Kebidanan, perlindungan hukum dalam pelayanan kebidanan oleh bidan praktik mandiri, merupakan amanah dan perintah ketentuan perundang-undangan sebagai bentuk perlindungan pasien yang ketentuanya terdapat dalam Pasal 2 huruf (f) dan huruf (g), yaitu penyelenggaraan kebidanan berasaskan (f) Perlindungn dan (g) Keselamatan Klien.

Selain itu berdasarkan Undang-Undang Nomor 36 tahun 2009 tentang Kesehatan berisi perlindungan hukum bagi pasien, antara lain :

Pasal 56 berbunyi :

(1) Setiap orang berhak menerima atau menolak sebagian atau seluruh tindakan pertolongan yang akan diberikan kepadanya setelah menerima dan memahami informasi mengenai tindakan tersebut secara lengkap. Hak menerima atau menolak sebagaimana dimaksud pada ayat (1) tidak berlaku pada penderita penyakit yang penyakitnya dapat secara cepat menular dalam masyarakat yang lebih luas, keadaan seseorang yang tidak sadarkan diri, atau gangguan mental berat;

(2) Ketentuan mengenai hak menerima atau menolak sebagaimana dimaksud pada ayat (1) diatur sesuai dengan ketentuan peraturan perundang-undangan.

Pasal 57 berbunyi : 
(1) Setiap orang berhak atas rahasia kondisi kesehatan pribadinya yang telah dikemukakan kepada penyelenggaraan pelayanan kesehatan;

(2) Ketentuan mengenai hak atas rahasia kondisi kesehatan pribadi sebagaimana dimaksud pada ayat (1) tidak berlaku dalam hal perintah undang-undang, perintah pengadilan, izin yang bersangkutan, kepentingan masyarakat, atau kepentingan orang tersebut.

Pasal 58 berbunyi :

(1) Setiap orang berhak menuntut ganti rugi terhadap seseorangm tenaga kesehatan dan/atau penyelenggara kesehatan yang menimbulkan kerugian akibat kesalahan atau kelalaian dalam pelayanan kesehatan yang diterimanya.

(2) Tuntutan ganti rugi sebagaimanan dimaksud pada ayat (1) tidak berlaku bagi tenaga kesehatan yang melakukan tindakan penyelematan nyawa atau pencegahan kecacatan seseorang dalam keadaan darurat

(3) Ketentuan mengenai tata cara pengajuan tuntutan sebagaiman pada ayat (1) diatur sesuai dengan ketentuan peraturan perundang-undangan.

Selain pasal-pasal diatas, berkaitan penyelenggaraan praktik bidan mandiri tertuang dalam Permenkes 1464 tahun 2016 tentang Izin dan Penyelenggaraan Praktik Bidan. Adapun Pasal 18 butir (1) yang berbunyi :

"Dalam melaksanakan praktik/kerja, bidan berkewajiban untuk menghormati hak pasien, memberikan informasi tentang masalah kesehatan pasien dan pelayanan yang dibutuhkan, merujuk kasus yang bukan kewenanganya atau tidak dapat ditangani dengan tepat waktu, meminta persetujuan tindakan yang akan dilakukan, menyimpan rahasia pasien sesuai dengan ketentuan peraturan perundang-undangan, melakukan pencatatan asuhan kebidanan dan pelayanan lainya secara sistematis, mematuhi standar dan melakukan pencatatan dan pelaporan penyelenggaraan praktik kebidanan termasuk pelaporan kelahiran dan kematian"

Dari uraian di atas penulis dapat merumuskan menjadi dua pertanyaan, yang pertama bagaimana perlindungan hukum terhadap pasien yang mengalami kerugian pada pelayanan kesehatan bidan praktik mandiri di Indonesia ? kedua bagaimana peran Ikatan Bidan Indonesia (IBI) dalam pembinaan, pengawasan dan pemberian sanksi terhadap Bidan Praktik Mandiri ? Jenis penelitian dalam penulisan huku ini adalah penelitian hukum normatif atau penelitian kepustakaan yaitu penelitian hukum dengan cara meneliti bahan-bahan pustaka atau data sekunder yang terdiri dari bahan hukum primer.

\section{PEMBAHASAN}

\section{a. Perlindungan Hukum Pasien yang Mengalami Kerugian Pada Pelayanan Kesehatan Bidan Praktek Mandiri di Indonesia}

Dalam teori Perlindungan hukum, munculnya teori ini adalah bersumber dari teori hukum alam atau aliran hukum alam yang dipelopori oleh Plato, Aristoteles dan Zeno. Perlindungan hukum menurut Fiztgerald sebagaimana dikutip Satjipto Raharjo adalah upaya untuk melindungi kepentingan seseorang dengan cara mengalokasikan suatu kekuasaan kepadanya untuk bertindak dalam kepentingan tersebut. 
Salah satu sifat dari tujuan hukum adalah untuk memberikan perlindungan, pengayoman, kepada masyarakat. Maka dari itu perlindungan hukum terhadap masyarakat harus diwujudkan dalam bentuk adanya kepastian hukum (Satjipto Raharjo, 1983:121).

Menurut Setiono, perlindungan hukum adalah tindakan atau upaya untuk melindungi masyarakat dari perbuatan sewenang-wenang oleh penguasa yang tidak sesuai dengan aturan hukum, untuk mewujudkan ketertiban dan ketentraman sehingga memungkinkan manusia untuk menikmati martabatnya sebagai manusia (Setiono 2004: 3), sedangkan menurut Muchsin, perlindungan hukum merupakan kegiatan untuk melindungi individu dengan menyerasikan hubungan nilai-nilai atau kaidah-kaidah yang menjelma dalam sikap dan tindakan dalam menciptakan adanya ketertiban dalam pergaulan hidup antar sesama manusia. Perlindungan hukum sebagai salah satu hal yang melindungi subyeksubyek hukum melalui peraturan perundang-undangan yang berlaku dan dipaksakan pelaksanaannya dengan suatu sanksi. Perlindungan hukum dibedakan menjadi 2 yaitu (Muchsin, 2003:14) :

a. Perlindungan hukum preventif

Perlindungan yang diberikan oleh pemerintah dengan tujuan untuk mencegah sebelum terjadinya pelanggaran. Hal ini terdapat dalam peraturan perundangundangan dengan tujuan untuk mencegah suatu pelanggaran serta memberikan rambu-rambu atau batasan untuk melakukan suatu kewajiban.

b. Perlindungan hukum represif

Perlindungan hukum represif adalah perlindungan akhir berupa sanksi seperti denda, penjara, dan hukuman tambahan yang diberikan apabila sudah terjadi sengketa atau telah dilakukan suatu pelanggaran.

Perlindungan hukum pasien berkaitan dengan Undang-Undang Nomor 36 Tahun 2009 yang didalamnya mengatur tentang hak dan kewajiban pasien dan hak kewajiban tenaga kesehatan sehingga tercipta suatu hubungan hukum antara pasien dan tenaga kesehatan sehingga menimbulkan perlindungan hukum yang diberikan kepada pasien. Hubungan hukum antara pasien dengan tenaga kesehatan timbul pada saat pasien menghubungi dokter untuk meminta bantuan terhadap kesehatannya karena tenaga kesehatan dianggap sebagai perantara yang dapat menyembuhkan penyakitnya. Dokter merasa mampu mengobati pasiennya dan pasien mendapatkan tindakan dari tenaga kesehatan yang merawatnya. Pasien yang awam tentang kesehatan percaya pada dokter, bidan atau tenaga kesehatan lainnya dalam menangani kesehatannya. Dokter, Bidan atau tenaga kesehatan lain dalam memberikan pelayanan terhadap pasien harus dengan asas keadilan, artinya dalam memberikan pelayanan kesehatan terhadap pasien tidak memandang status sosial dan ekonomi pasien, mengutamakan hak dan kenyamanan pasien. Dokter, Bidan dan tenaga kesehatan lainnya juga harus memberikan informasi tentang penyakit yang diderita pasien secara benar dan 
jujur dengan tetap menjaga rahasia tentang penyakit yang diderita pasien. (Willa Chandra, 2001: 52)

Perlindungan hukum terhadap pasien juga tidak hanya diberikan oleh Dokter, Bidan dan tenaga kesehatan saja, Dinas Kesehatan yang menaungi tentang masalah di bidang kesehatan juga wajib memberikan perlindungan hukum sebagai bentuk tanggung jawab pemerintah terhadap pasien yang mengalami kelalaian yang disebabkan oleh tenaga kesehatan dalam pelayanan kesehatan. Selain Dinas Kesehatan, organisasi profesi tenaga kesehatan seperti Ikatan Dokter Indonesia (IDI), Ikatan Bidan Indonesia (IBI), Persatuan Perawat Nasional Indonesia (PPNI),dll juga wajib memberikan perlindungan hukum terhadap pasien yang mengalami kelalaian pada pelayanan kesehatan yang diberikan oleh tenaga kesehatan sebagai bentuk tanggung jawab organisasi profesi yang menaungi tenaga kesehatan tersebut. (Niah Mufhidin, 2017: 22)

Perlindungan hukum terhadap pasien sebagai konsumen bidan praktik mandiri yang ditijau dari undang-undang kebidanan dan undang-undang kesehatan. Bidan praktik mandiri adalah salah satu tenaga medik di indonesia yang jumlahnya sangat banyak sehingga mudah diakses oleh masyarakat. Pasien adalah konsumen bidan sehingga pasien tidak hanya dilindungi oleh undangundang kesehatan tetapi juga oleh undang-undang kebidanan. Bidan sebagai pemberi jasa pelayanan kesehatan bertanggung jawab terhadap tindakannya terhadap pasiennya karena hubungan pasien dan bidan yaitu bahwa bidan menjamin setiap tindakanya dalam melakukan tugasnya akan berupaya maksimal untuk menyebuhkan pasien. (Niah Mufhidin, Ibid: 28).

Bentuk perlindungan hukum dalam Undang-Undang No. 4 Tahun 2019 tentang Kebidanan, bagi pasien pada pelayanan bidan praktek mandiri di Indonesia terdapat dalam Pasal 62, yang berbunyi :

"Dalam Praktik Kebidanan, Klien berhak:

a. Memperoleh pelayanan kebidanan sesuai dengan kompetensi, kode etik, standar profesi, standar pelayanan dan standar pelayanan prosedur;

b. Memperoleh informasi yang benar dan jelas mengenai kesehatan klien, termasuk resume isi rekam medis jika diperlukan;

c. Meminta pendapat Bidan lain;

d. Memberi persetujuan atau penolakan tindakan Kebidanan yang akan dilakukan; dan

e. Memperoleh jaminan kerahasiaan kesehatan Klien."

Kemudian dalam hal kerahasiaan Klien diatur perlindungan dalam Pasal 63, berbunyi :

(1) Pengungkapan rahasia kesehatan Klien hanya dilakukan atas dasar :

a. Kepentingan kesehatan Klien;

b. Permintaan aparatur penegak hukum dalam rangka penegakan hukum;

c. Persetujuan Klien sendiri; dan/atau

d. Ketentuan peraturan perundang-undangan

(2) Pengungkapan rahasia kesehatan Klien sebagaimana dimaksud pada ayat (1) terbatas pada tindakan yang dilakukan oleh Bidan; 
(3) Ketentuan lebih lanjut mengenai pengungkapan rahasia Klien diatur dalam Peraturan Menteri.

\section{b. Peran Ikatan Bidan Indonesia (IBI) Dalam Pembinaan, Pengawasan Dan Pemberian Sanksi}

Ikatan Bidan Indonesia (IBI) bertindak dalam kapasitasnya sebagai pejabat selaku badan organisasi profesi bidan mempunyai tugas dan tanggungjawab dalam perlindungan hukum bagi pasien serta berkewajiban melakukan pengawasan mutu pelayanan kebidanan. Aspek perlindungan hukum mengatur dan menentukan hak dan kewajiban masing-masing subyek hukum.

Pengaturan hak dan kewajiban tersebut antara pasien dan bidan tercantum dalam Permenkes 1464 tahun 2010 tentang Izin dan Penyelenggaraan Praktik Bidan. Untuk menjaga terlaksananya hak dan kewajiban tersebut diperlukan pengawasan dari berbagai pihak, utamanya IBI. (Ari Yunanto, Ibid: 61)

Selain itu bentuk perlindungan hukum tercermin dalam STR dan SIP, serta sertifikat kompetensi pelatihan. IBI melakukan pengawasan kepada bidan praktik mandiri dalam bentuk pengawasan secara preventif. Adapun tujuan pengawasan preventif ini untuk mencegah supaya tidak terjadi penyimpangan oleh bidan praktik mandiri dalam memberikan pelayanan kebidanan. Pengawasan preventif ini meliputi penilaian kemampuan keilmuan dan ketrampilan (kompetensi) serta kepatuhan bidan terhadap kode etik profesi dan kesanggupan melakukan praktik mandiri secara terus menerus dan berkesinambungan.

Sebagai salah satu contoh berdasarkan hasil penelitian, bentuk perlindungan hukum bagi pasien dari pelayanan kebidanan oleh bidan praktik mandiri yang dilakukan IBI Cabang kabupaten Rembang adalah dengan melaksanakan Peraturan Bupati No. 41 Tahun 2011 tentang Percepatan Penurunan AKI dan AKB yang mengatur bahwa seluruh persalinan wajib ditempat fasilitas kesehatan pemerintah, tidak di bidan praktik mandiri. Di dalam ketentuan tersebut terdapat perkecualian, yaitu beberapa bidan praktik mandiri masih diperbolehkan menolong persalinan dengan memenuhi persyaratan dari Dinas Kesehatan Kabupaten Rembang yang dalam SIP masih berbunyi pertolongan persalinan normal.

Sejak dikeluarkannya peraturan bupati tersebut, diketahui bahwa terjadi penurunan bidan praktik mandiri dimana yang semula 332 menjadi 182 bidan praktik mandiri yang masih aktif. Peraturan tersebut tidak lain bertujuan perlindungan hukum bagi pasien khususnya kesehatan ibu, yang mana IBI menjalankan amanah dari ketentuan tersebut. IBI mewajibkan setiap anggota mengikuti pelatihan. Adapun bentuk pelatihan yang saat ini diprogramkan adalah Asuhan Persalinan Normal (APN). Sedangkan dari internal IBI sendiri untuk bentuk pengawasan preventif melalui penilaian, pelatihan, seminar dan sosialisasi kepada bidan praktik mandiri.

Namun demikian, dijumpai SIP yang sudah kadaluwarsa tapi bidan tersebut masih melakukan pelayanan. Hal ini tentu menjadi bentuk pelanggaran hukum bidan yang tidak menaati peraturan yang mana beresiko tidak terwujudnya perlindungan hukum baik bagi bidan dan pasien. Bentuk penilaian kepada bidan praktik mandiri hanya dilakukan apabila akan perpanjangan masa berlaku SIP dan STR. 
Bentuk pelatihan IBI Cabang Kabupaten Rembang antara lain pelatihan Asuhan Persalinan Normal (APN), Resusitasi Bayi Baru Lahir, Pemberian MgSO4 pada penanganan Pre Eklamsia, pelatihan pemeriksaan kanker serviks (IVA), pelatihan KB safari.

Sedangkan bentuk penilaian dan pelatihan ini belum dilakukan secara berkala dan berkesinambungan. Hal ini diketahui dengan penilaian kompetensi hanya dilakukan ketika akan perpanjangan SIP dan STR, sedangkan penilaian secara rutin diluar pengurusan SIP dan STR belum ada. Adapun bentuk pelatihan IBI Cabang Kabupaten Rembang mengacu program dari Pengurus Pusat IBI dan Pengurus Daerah IBI, sehingga untuk pelatihan secara mandiri oleh Pengurus Cabang kepada anggota belum ada.

Di samping itu, IBI Cabang Kabupaten Rembang belum bisa mengakomodasi pelatihan dan seminar untuk setiap anggotanya, hanya mereka, hanya mereka yang ditunjuk oleh Puskesmas untuk mengikuti pelatihan dan seminar. Dengan demikian peran IBI dalam perlindungan hukum bagi pasien dalam pelayanan kesehatan oleh bidan praktik mandiri melalui pengawasan preventif ini belum maksimal. Yang mana seharusnya IBI melakukan penilaian kemampuan keilmuan dan ketrampilan (kompetensi) bidan praktik mandiri secara terus menerus dan berkesinambungan, namun IBI Cabang Kabupaten Rembang belum melaksanakan sesuai tugas dan tanggungjawabnya dalam mewujudkan perlindungan hukum bagi pasien. (http://repository.unika.ac.id/ 13446/3 /13.93.0064\%20Mahmudah\%20Khusnul\%20Khotimah\%20BAB\%20III.pdf, diakses hari selasa, 9 Juli 2019 ,jam 09:35. wib)

Dilihat dari segi kedudukan badan atau organ yang berwenang mengawasi, bentuk pengawasan yang dilakukan oleh IBI, pengawasan intern merupakan pengawasan yang dilakukan oleh suatu badan yang mana secara organisatoris atau struktural masih termasuk dalam lingkungan pemerintahan itu sendiri. Hal tersebut merupakan IBI organisasi profesi bidan yang berwenang mengatur para anggota dengan melakukan pengawasan guna menjaga dan meningkatkan mutu pelayanan kebidanan adapun pengawasan berupa rapat organisasi, pelatihan, seminar serta sosialisasi peraturan terbaru.

Bentuk pengawasan oleh IBI terhadap pelaksanaan kewenangan bidan praktik dilihat dari segi waktu pengawasan merupakan pengawasan preventif. Pengawasan preventif sendiri adalah pengawasan yang dilakukan sebelum dikeluarkannya suatu keputusan atau ketetapan Pemerintah dengan maksud agar tidak ada kesalahan atau penyimpangan dalam melakukan kegiatan organisasi. IBI bertugas dan bertanggungjawab menjaga, mengendalikan mutu pelayanan dan pengabdian profesi bidan secara terus menerus. Adapun bentuk pengawasan preventif oleh IBI yaitu dengan melakukan penilaian kemampuan keilmuan keterampilan (kompetensi) ketika pengajuan ijin praktik berupa surat rekomendasi praktik mandiri. Selain itu, kepatuhan terhadap kode etik profesi bidan dan kesanggupan untuk melakukan praktik mandiri melalui rapat pertemuan cabang, ranting dan kelompok, serta mengawasi pelaksanaan pelayanaan kebidanaan melalui pelatihan dan seminar.

Sedangkan kewenangan bidan praktik mandiri sesuai permenkes 1464 tahun 2010 tentang izin dan penyelenggaran praktik bidan pasal 9 yang berbunyi : 
"Bidan dalam menjalaankan praktik, berwenang untuk memberikan pelayanaan yang meliputi :

a. Pelayanan kesehatan ibu;

b. Pelayanana kesehatan anak; dan

c. Pelayanana kesehatan reproduksi perempuan dan keluarga berencana.

Selain itu aturan terbaru Undang-Undang No. 4 tahun 2019 tentang Kebidanan terkait pembinaan Bidan Praktik Mandiri terdapat dalam Pasal 61, menyebutkan :

"Bidan dalam melaksanakan melaksanakan praktik kebidanan berkewajiban :

a. Memberikan pelayanan kebidanan sesuai dengan kompetensi, kewenangan, dan mematuhi kode etik, standar profesi, standar pelayanan profesi, standar prosedur operasional;

b. Memberikan informasi yang benar, jelas dan lengkap mengenai tindakan kebidanan kepada klien dan/atau keluarganya sesuai kewenanganya;

c. Memperoleh persetujuan dari klien atau keluarganya atas tindakan yang akan diberikan;

d. Merujuk klien yang tidak dapat ditangani ke dokter atau fasilitas pelayanan kesehatan;

e. Mendokumentasi asuhan kebidanan sesuai dengan standar;

f. Menjaga kerahasiaan kesehatan klien;

g. Menghormati hak klien;

h. Melaksanakan tindakan pelimpahan wewenang dari dokter sesuai dengan kompetensi bidan;

i. Melaksanakan penugasan khusus yang ditetapkan oleh peraturan pusat;

j. Meningkatkan mutu pelayanan kebidanan;

k. Mempertahankan dan meningkatkan pengetahuan dan/atau keterampilanya melalui pendidikan dan/atau pelatihan;dan/atau

l. Melakukan pertolongan gawat darurat.

Terkait pengawasan dan sanksi pemasangan papan nama Bidan Praktik Mandiri terdapat dalam Undang-Undang No. 4 tahun 2019 Pasal 44 menyebutkan :

(1) Bidan lulusan pendidikan profesi yang menjalankan praktik kebidanan di tempat praktik mandiri bidan wajib memasang papan nama praktik;

(2) Ketentuan mengenai papan nama praktik sebagaimana dimaksud pada ayat (1) dilaksanakan sesuai dengan ketentuan peraturan perundangundangan;

(3) Bidan yang tidak memasang papan nama praktik sebagaiana dimaksud pada ayat (1) dikenai sanksi administratif berupa
a. Teguran lisan;
b. Peringatan tertulis
c. Denda administratif;dan/atau
d. Pencabutan izin 
(4) Ketentuan lebih lanjut mengenai tata cara pengenaan sanksi administratif sebagaimana dimaksud pada ayat (3) diatur dengan peraturan Menteri

Kemudian terkait pengawasan dan sanksi sarana dan prasarana pelayanan kesehatan Bidan Praktik Mandiri terdapat dalam Undang-Undang No. 4 Tahun 2019 Pasal 45, yaitu :

(2) Bidan yang menjalankan Praktik kebidanan di Tempat Praktik Mandiri Bidan wajib melengkapi sarana dan prasarana pelayanan sesuai dengan standar pelayanan dan ketentuan peraturan perundang undangan;

(3) Bidan yang tidak melengkapi sarana dan prasaranan pelayanan sebagaimana dimaksud pada ayat (1) dikenai sanksi administratif berupa :
a. Teguran lisan;
b. Teguran tertulis;
c.Denda administratif;dan/atau
d. Pencabutan izin

(4) Ketentuan mengenai tata cara pengenaan sanksi administratif sebagaimana dimaksud pada ayat (2) diatur dengan Peraturan Menteri.

Kewenangan bidan praktik mandiri yang tersebut diatas merupakan keweangan atributif dimana kewenangan tersebut merupakan kewenangan asli atau kewenangan yang melekat tidak dibagi-bagikan pada siapapun, hanya bidan praktik mandiri yang mempunyai STR dan SIP yang berlaku diberikan kewenangan memberikan pelayananan kesehatan tersebut. Diketahui bahwa pada pelaksanaan kewenangan bidan praktik mandiri disetiap daerah sesuai dengan peraturan yang berlaku, namun masih terdapat beberapa bentuk pelanggaran diluar kewenangan bidan praktik mandiri yakni, berupa pelayanan pengobatan orang sakit, menjual susu formula.

Ikatan Bidan Indonesia (IBI) mempunyai peran pengawasan terhadap Bidan Praktik Mandiri, berdasarkan peraturan perundang-undangan yakni Undang-Undang No. 36 tahun 2009 tentang Kesehatan, Undang-Undang No. 36 tahun 2014 tentang tenaga kesehatan, Permenkes No. 1464 tahun 2010 Izin dan Penyelenggaraan Praktik Bidan, serta aturan terbaru Undang-Undang No. 4 tahun 2019 tentang Kebidanan. Ikatan Bidan Indonesia (IBI) mempunyai peran imperatif dalam pengawasan terhadap Bidan Praktik Mandiri. Pengawasan oleh IBI berupa pengawasan preventif meliputi penilaian kompetensi, pelatihan, seminar. Sedangkan pengawasan represif berupa pemberian sanksi. Ikatan Bidan Indonesia telah melakukan pengawasan tersebut.

\section{PENUTUP}

Berdasarkan uraian diatas dapat disimpulkan Perlindungan hukum terhadap pasien adalah teori yang menjelaskan adanya upaya melindungi kepentingan seseorang dengan cara mengalokasikan suatu kekuasaan kepadanya untuk bertindak dalam kepentingannya tersebut. Kemudian salah satu sifat dan tujuan dari hukum adalah untuk memberikan perlindungan, pengayoman kepada masyarakat. Bentuk perlindungan hukum yang diberikan kepada Pasien yang merasa dirugikan pada pelayanan kesehatan Bidan Praktik Mandiri terdapat upaya hukum preventif (pencegahan) dan upaya hukum represif (tindakan). 
Menurut Undang-Undang No. 4 tahun 2019 tentang Kebidanan perlindungan hukum terhadap Pasien terdapat dalam Pasal 61 dan Pasal 62. Peran Ikatan Bidan Indonesia (IBI) adalah melakukan pengawasan preventif (pencegahan) yaitu pengawasan yang dilakukan sebelum dikeluarkannya suatu keputusan atau ketetapan Pemerintah dengan maksud agar tidak ada kesalahan atau penyimpangan dalam melakukan kegiatan organisasi. IBI bertugas dan bertanggungjawab menjaga, mengendalikan mutu pelayanan dan pengabdian profesi bidan secara terus menerus.

Selain itu juga bentuk pengawasan preventif oleh Ikatan Bidan Indonesia (IBI) yaitu dengan melakukan penilaian kemampuan keilmuan keterampilan, kompetensi ketika pengajuan ijin praktik berupa surat rekomendasi praktik mandiri. Selain itu, kepatuhan terhadap kode etik profesi bidan dan kesanggupan untuk melakukan praktik mandiri melalui rapat pertemuan cabang, ranting dan kelompok, serta mengawasi pelaksanaan pelayanaan kebidanaan melalui pelatihan dan seminar. Bentuk pengawasan represif (tindakan) yang dilakukan adalah terdapat dalam Undang-Undang No. 4 Tahun 2019 tentang Kebidanan dengan sanksi Pasal 44 dan Pasal 45 dari pemberian sanksi administratif berupa teguran lisan, teguran tertulis, denda administratif hingga pencabutan izin Bidan Praktik Mandiri.

\section{DAFTAR PUSTAKA}

\section{A. Buku}

C.S.T Kansil. 1989. Pengantar Ilmu Hukum dan Tata Hukum Indonesia. Jakarta: Balai Pustaka.

Rahardjo, Soetjipto. 1983. Permasalahan Hukum Di Indonesia. Bandung: Alumni.

Setiono. 2004. Rule Of Law (Supremasi Hukum). Surakarta: Magister Ilmu Hukum Program Pascasarjana Universitas Sebelas Maret.

Muchsin. 2003. Perlindungan dan Kepastian Hukum Bagi Investor di Indonesia. Surakarta, Magister Ilmu Hukum Program Pascasarjana Universitas Sebelas Maret.

Chandra, Willa. 2001. Hukum Kedokteran. Bandung: Mandar Maju.

Heni, P.W. dan Asmar Y.Z. 2005. Etika Profesi Kebidanan. Yogyakarta : Fitrimaya.

\section{B. Peraturan Perundang-undangan}

Undang-Undang Dasar 1945 Amandemen

Undang-undang Nomor 36 Tahun 2014 tentang Tenaga Kesehatan

Undang-undang Nomor 4 Tahun 2019 tentang Kebidanan 


\section{Sumber lainnya}

https://news.detik.com/berita/d-3168361/bayi-meninggal-dalam-kondisimengenaskan-pasutri-di-palembang-laporkan-bidan, diakses pada selasa, 2 juli 2019, jam 18.05 WIB

https://manaberita.com/2017/12/malpraktek-dari-rahim-jebol-sampai-dijahitacak-acakan-ibu-satu-anak-ini-curhat-di-facebook/, diakses pada selasa, 2 juli 2019, jam 18.10 WIB

https://www.antaranews.com/berita/398499/polisi-selidiki-dugaan-malpraktikseorang-bidan, diakses pada Selasa, 2 Juli 2019, jam 18.45 WIB

https://megapolitan.kompas.com/read/2015/02/16/1813575/Bayinya.Meningga l.Pita.Laporkan.Dokter.dan.Bidan.ke.Polisi, diakses pada Selasa, 2 Juli 2019, jam 18.48 WIB

https://prasko17.blogspot.com/2011/03/perbedaan-malpraktek-dan-kelalaian. html,diakses hari selasa, 9 Juli 2019 ,jam 09:35. Wib

(http://repository.unika.ac.id/13446/3/13.93.0064\%20Mahmudah\%20Khusnul \%20Khotimah\%20BAB\%20III.pdf, diakses hari selasa, 9 Juli 2019 ,jam 09:35. wib 


\section{PEDOMAN PENULISAN JURNAL PRANATA HUKUM}

1. Naskah bersifat orisinil, baik berupa hasil riset atau tinjauan atas suatu permasalahan hukum yang berkembang di masyarakat (artikel lepas), dimungkinkan juga tulisan lain yang dipandang memberikan kontribusi bagi pengembangan ilmu hukum.

2. Penulisan terdiri atas beberapa bab penulisan hasil penelitian terdiri dari 3BAB,yaitu ;

BAB I. PENDAHULUAN (Latar Belakang dan Rumusan Masalah) BAB II. PEMBAHASAN (Kerangka Teori dan Analisis), dan BAB III. PENUTUP (Kesimpulan dan Saran).

3. Tulisan menggunakan bahasa indonesia maupun bahasa inggris yang memenuhi kaidah bahasa yang baik dan benar,tulisan menggunakan bahasa indonesia disertai abstrak dalam bahasa inggris (200 kata) dan Kata kunci, ketentuan ini berlaku sebaliknya.

4. Setiap kutipan harus menyebutkan sumbernya, dan ditulis pada akhir kutipan dengan memberi tanda kurung (bodynote). Sumber kutipan harus memuat nama pengaran, tahun penerbitan dan halaman .Contoh : satu penulis (Bagir Manan, 1994: 20), Dua Penulis (Jimly Asshidiqqie dan M.Ali Syafa'at, 2005: 11), Tiga atau lebih penulis menggunakan ketentuan et.al (dkk). Untuk artikel dari internet dengan susunan: nama penulis, judul tulisan digaris bawah, alamat website, waktu download/unduh.

5. Naskah harus disertai dengan daftar pustaka atau referensi ,terutama yang digunakan sebagai bahan acuan langsung. Daftar pustaka dan referensi bersifat alfabetis dengan format; nama pengarang, judul buku, nama penerbit, kota terbit, dan tahun penerbitan. Contoh: Bagir Manan, Hubungan Antara Pemerintah Pusat dan Daerah Menurut UUD 1945, Pustaka Sinar Harapan, Jakarta, 1994.

6. Panjang tulisan antara 15-25 halaman, font times new roman dengan 1,15 spasi. Dalam hal hal tertentu berlaku pengecualian panjang tulisan.

7. Naskah disertai nama lengkap penulis, alamat e-mail dan lembaga tempat berafiliasi saat ini, dan hal lain yang dianggap penting. 


\section{Jurnal PRANATA HUKUM dimaksudkan sebagai}

media komunikasi, edukasi, dan informasi ilmiah bidang ilmu hukum khususnya, dan ilmu sosial pada umumnya. Sajian dan kemasan diupayakan komunikatif melalui bahasa ilmiah.

Redaksi mengundang semua elemen masyarakat baik civitas akademika, praktisi, lembaga masyarakat, maupun perorangan yang berminat terhadap bidang hukum untuk berpartisipasi mengembangkan gagasan, wawasan, dan pengetahuan melalui tulisan untuk dimuat dalam jurnal ini.

Melalui PRANATA HUKUM diharapkan terjadi proses pembangunan dan pengembangan bidang hukum sebagai bagian penting dari rangkaian panjang proses memajukan masyarakat bangsa.

Alamat Redaksi

PRANATA HUKUM

Kampus B Universitas Bandar Lampung Jl. ZA Pagar Alam No.89 Labuhan Ratu, Bandar

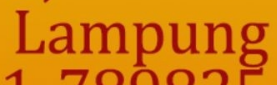

Telp: 0721-789825

Email: jurnal.mh@ubl.ac.id

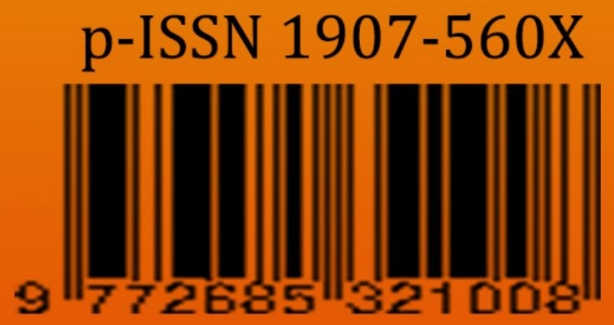

